\title{
Environmental Integration of Wind Farms: The Territorial Governance
}

\author{
Francesco Ruggiero, Graziarosa Scaletta \\ Dipartimento di Scienze dell'Ingegneria Civile e dell'Architettura, Politecnico di Bari, Bari, Italy \\ Email: ruggiero@poliba.it, arch.g.s.scaletta@gmail.com
}

Received 25 July 2014; revised 20 August 2014; accepted 8 September 2014

Copyright (C) 2014 by authors and Scientific Research Publishing Inc.

This work is licensed under the Creative Commons Attribution International License (CC BY). http://creativecommons.org/licenses/by/4.0/

(c) (i) Open Access

\begin{abstract}
This research arises from the need to investigate the phenomenon of the development of wind farms in Puglia and the aspects related to the environmental impact that these systems generate on the territory. This represents a sign of change and adaptation on landscapes for people and local governments. The demand and the need to install renewable energy systems must be mediated by the preservation of the landscape and governed by planning instruments, which in this case should be expanded with a strategic energy planning in the anthropized environment that is being examined. With a careful analysis of the current situation, this paper suggests, a model of integrated development in which technology, landscape and bureaucracy reach an almost perfect balance between the protection of the territory and the incessant vicious speculative and criminal process.
\end{abstract}

\section{Keywords}

Wind Farm, Environmental Planning, Renewable Energy and Sustainability

\section{Introduction}

This work extends a recent research on the development of energy production from wind power in the Mediterranean area and, in particular, in Puglia [1] [2]. Here the focus is on the landscape evaluation for wind farms. This is a subject of great relevance due to the increasing development of wind energy in recent years in some European countries (e.g., France, Spain, England), and especially in Italy. The need for this study is the result not only of the growing commitment to sustainable development, but also of more general policies to ensure a widespread landscape quality for which the principles of the European Landscape Convention (Florence, 2000) represent a fundamental reference.

Several researchers have addressed the issues of territorial integration [3]-[10] often focusing on specific as- 
pects such as environmental impact, visual impact, noise impact, and social impact. Here we propose a different methodology of systematic approach to plan the placement of wind farms on the landscape.

In recent years, an exponential growth of wind power plants in Puglia has been observed. In fact, in December 2011 the installed capacity was $1393.5 \mathrm{MW}$, an increase of $220 \%$ over the previous year [11], and these data are still growing.

Looking at the data, the landscape sustainability issue is becoming a necessity, an urgency, but also an opportunity. It is combined with ethical choices related to the most important issues of our time: peace, security and social environmental, sustainable and equitable development, a better distribution of resources and social opportunities.

This proposal aim not simply to insert the wind generator in the area as a foreign object, but as a project able to rethink the area, actualizing the meanings and uses, and ensuring that the transformations become an integral part of the existing area, that is to say the new landscapes: the energy landscapes.

The technological innovation of a wind farm and the benefits of clean energy need to coexist with a strongly characterized and anthropized area, without generating damage to the regional landscape.

For these reasons, the knowledge of the physical characteristics of the current regional landscape contexts, their historical formation, historical meanings and those attributed to them by their communities is fundamental. Each site must be read and interpreted so that the wind farm project will itself become a characteristic of the landscape and its forms contribute to the recognition of its own peculiarity, building a coherent relationship within the existing context. The wind project must become a new landscape plan to better integrate the context.

Wind plants are linked to a form of energy that depends on the availability of wind resources that requires the location of the plants in specific areas. Unsuitable locations, which most often pertain to beautiful countryside, has originated a heated debate on the benefits produced that are insufficient compared to the territory impact and, above all, on the perception of the landscape.

The energy planning must take into account the great and diffused historical, architectural, morphological and natural quality of Puglia landscapes. The evident impacts of wind turbines on landscape (especially in cases of wind generators over $50 \mathrm{~m}$ height) have slowed projects which, although their impacts are not comparable with thermo-electric systems, they represent a necessary way to achieve the objectives to protect the future of our planet agreed by the international community [12].

The real impacts on the environment and landscape are shown in Table 1.

The main problem is a proper contextualization of the plants and we should not underestimate the effects generated by the presence of several plants (cumulative impact). To consider the cumulative effects on the landscape means to estimate the distance between the plants, the relationships between the respective visual areas of influence as well as the general characters of the landscape [13]. Hence it is required to rationalize the number of wind turbines in the area in a single intervention in a way which avoids "the forest effect", in other words a "crowding" of turbines on the affected area.

Another important aspect concerns the bureaucratic issues, the problems related to the choice of a good design

Table 1. Wind farm impacts on the environment and landscape $\left(^{*}\right)$.

\begin{tabular}{ll}
\hline Causes & Effects \\
Visual impact & $\begin{array}{l}\text { changes to the landscape and visual scenario in the surrounding context of } \\
\text { the wind farm } \\
\text { wind farms modify the ground but not the visual impact so much } \\
\text { (so that it is always possible to restore the original sites), allowing crops and } \\
\text { usual agricultural practices }\end{array}$ \\
Nerritorial impact & $\begin{array}{l}\text { it is mainly due to the movement of the rotors of the wind turbines which } \\
\text { generates noise especially at the ends of the blades } \\
\text { Electromagnetic disturbances }\end{array}$ \\
$\begin{array}{l}\text { it is due to the presence of big rotors, but they are restricted only to } \\
\text { surrounding areas of the wind farm and they mainly concern interference } \\
\text { with radio waves }\end{array}$ \\
$\begin{array}{l}\text { integration of wind farms in areas with high wildlife interest } \\
\text { (especially wetlands) in which there are birds considered protected or } \\
\text { endangered species and migratory routes }\end{array}$
\end{tabular}

( ${ }^{*}$ Source: Guidelines for the planning and siting of renewable energy plant, Puglia Region. 
and, above all, how to move into a jungle of proponents and inside different phases of the proposal-review and approval of a wind farm.

Authorization procedures for the construction of renewable energy plants in the Puglia region are provided by a national Law n. 387/2003) [14] and a regional law [15].

The incentive system used until a few months ago has resulted in a high financial speculation in the renewables sector with ethical problems such as the sale of agricultural land, including high-qualified and productivity in order to achieve a faster and easier gain thanks to the sale of energy rather than the sale of agricultural products.

At present the result is that only for the Puglia region, the authorization procedures in progress and completed cover plants with an energy production higher than the national electricity demand, demonstrating the futility of the continuous destruction of the territory. Therefore it is necessary to regulate the relations between plants and tools in territorial governance and the transformation projects that follow.

This task is entrusted to the Town Planning, which should lay down rules, conditions and opportunities for the use of local energy capacity in relation to specific tissues and forms of settlement of the territory as well as the good sense of designers and production companies.

\section{Criteria for the Correct Design of a Wind Farm and Its Inclusion on the Territory}

The features that contribute to a potential impact on the landscape (positive or otherwise) for wind power plants are due mainly to their physical characteristics: the towers and the height of turbines, the number of towers, movement, colours and materials, etc.

The state of the impact depends on its size, thought as a rated power of energy produced, the plant itself, as well as by the distribution choices on the territory.

Tables 2-4 describe the characteristics and parameters of a wind power plant insertion on the territory.

The considerable size of a system is not often accompanied by a lay-out consistent with the structural elements of the landscape in which they occur, causing confusion and perceptual disturbance (forest effect). It is therefore necessary to control certain parameters linked to a location such as density, land use, and land form.

In addition to the critical nature of the perception, the construction of a system involves changes and transformations and if they are not controlled by a project, that is respectful of its natural setting or hydrogeological problems, or historical features of the site, could damage irreversibly the landscape.

For example, the opening of new roads has interrupted in some cases the continuity of natural areas for grazing; in other cases the wind turbines and the service roads have been located in areas classified as strongly dangerous from the geomorphological point of view, and this contribute to weaken the hillside.

Moreover, in respect to the settlement characteristic, there are also examples of proximity or overlap of windfarms to sites of archaeological interest. Finally, there are other examples on the proximity of the plants to urban centres in a position that does not take care of the structural elements and the identity elements of the site. This generates high levels of criticality and visual disturbance (Table 5).

\section{The Research Steps}

The aim of this research is the development of a model through the tool of GIS that is a source of information, technical support and critical guidance for policy-makers, administrators, operators and technicians involved in

\begin{tabular}{lll} 
Table 2. Different wind farm for size $\left(^{*}\right)$ & & \\
\hline Types of Wind Farm & $\begin{array}{l}\text { Generators } \\
\left(\mathbf{n}^{\circ}\right)\end{array}$ & $\begin{array}{l}\text { Rated Power } \\
\text { P (MW) }\end{array}$ \\
\hline Large Size & 1 or more & $>1$ \\
Medium Size & 1 or more & $0.50<\mathrm{P}<1$ \\
Miniwind & 1 & $0.50<\mathrm{P}<1$ \\
Microeolic & 1 or more & $<0.50$ \\
\hline
\end{tabular}

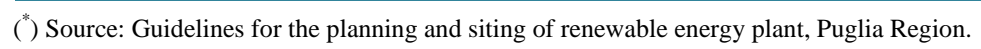


Table 3. Characteristics of the elements of a wind turbine.

\begin{tabular}{|c|c|c|}
\hline Reference & Characteristic & Description \\
\hline \multirow{7}{*}{ Turbine } & & - Horizontal-axis machines \\
\hline & Typology & $\begin{array}{l}\text { - Vertical-axis machines single-blade, bi-blade, tri-blade } \\
\text { (the choice is irrelevant, it depends on the geographical context; it is important } \\
\text { that the same wind area will adopt the same machine type to avoid visual disturbances) }\end{array}$ \\
\hline & Size & Diameter: max 90 m \\
\hline & Power & (cf. Table 1 ) \\
\hline & Colour & $\begin{array}{l}\text { Better neutral colours and opaque: light grey, beige, cream, but it is important } \\
\text { that they are integrated in the environment and that they comply aeronautical provisions. }\end{array}$ \\
\hline & & - wind pole \\
\hline & 1ур010zу & - pylon \\
\hline \multirow{11}{*}{ Tower } & Height & $\max 80-100 m$ \\
\hline & Width & \\
\hline & Colour & $\begin{array}{l}\text { Better neutral colours and opaque: light grey, beige, cream, but it is important } \\
\text { that they are integrated in the context. }\end{array}$ \\
\hline & \multirow{3}{*}{$\begin{array}{l}\text { Density } \\
\text { (distance between the } \\
\text { blades and between plants) }\end{array}$} & $\begin{array}{l}\text { - Concentration rather than dispersion: homogeneous groups of plants are preferable to } \\
\text { individual machines scattered throughout the territory. } \\
\text { (It is less the visual impact of a smaller number of larger turbines that a greater number } \\
\text { of smaller turbines). The minimum distance between wind turbines is suggested } 3 \text { - } 5 \\
\text { times the diameter of the rotor in the same row and } 5 \text { - } 7 \text { times the diameter of parallel rows } \\
\text { (Guidelines for the planning and siting of renewable energy plant, Puglia Region) }\end{array}$ \\
\hline & & $\begin{array}{l}\text { - To place the machines in groups of no more than eight turbines with a relatively } \\
\text { large distance between them (Danish Guidelines for the design of windfarms) }\end{array}$ \\
\hline & & $\begin{array}{l}\text { - German guidelines for the design of the windfarms provide more than } 5 \mathrm{~km} \\
\text { between wind plants }\end{array}$ \\
\hline & Distance from the town & $\begin{array}{l}\text { buffer of } 1000 \mathrm{~m} \text { for large wind farm and } 500 \mathrm{~m} \text { for small wind farm, both for reasons } \\
\text { of perception than urban planning (production areas are not considered because suitable } \\
\text { for the location of wind generators) }\end{array}$ \\
\hline & Distance from vegetation & buffer of $200 \mathrm{~m}$ \\
\hline & Distance from coast & $\begin{array}{l}\text { - buffer of } 300 \mathrm{~m} \text { from wind farm of any size and number of wind turbines } \\
\text { (except industrial and port areas, to be regulated in an appropriate way) }\end{array}$ \\
\hline & & - buffer of $2 \mathrm{~km}$ from power wind farm with more than $1 \mathrm{MW}$ \\
\hline & $\begin{array}{l}\text { Distance from restricted } \\
\text { areas }\end{array}$ & buffer of $500 \mathrm{~m}$ \\
\hline \multirow{5}{*}{$\begin{array}{l}\text { Infrastructure } \\
\text { and Services }\end{array}$} & Electrical substation & $\begin{array}{l}\text { It is preferable to use the existing substations, to reduce their number in the area } \\
\text { It is clear that this often leads to a lengthening of the electric transmission lines }\end{array}$ \\
\hline & Access roads & $\begin{array}{l}\text { It is preferable to use the existing road network and if necessary to adapt it to the } \\
\text { requirements of transport, construction and maintenance. It is important, finally, } \\
\text { paved roads with permeable surfaces (macadam or similar) }\end{array}$ \\
\hline & $\begin{array}{l}\text { Power transmission lines } \\
\text { and substations }\end{array}$ & $\begin{array}{l}\text { The distance from the network of high and medium voltage is of fundamental importance } \\
\text { to avoid problems of over-infrastructure of the territory. The distance between layout } \\
\text { and connection point must not be greater than } 8 \mathrm{~km} \text {. Furthermore, to ensure a low impact } \\
\text { underground electrical power grid lines is preferred, alongside the existing road network, } \\
\text { in accordance with local regulations }\end{array}$ \\
\hline & \multirow{3}{*}{ Service/Disposal } & - it must be guaranteed a constant access to the site \\
\hline & & $\begin{array}{l}\text { - in the case of decommissioning of the wind farm (the operating life is } \\
\text { approximatively thirty years), it is necessary to restore the area, ensuring the original use }\end{array}$ \\
\hline Noise & & $\begin{array}{l}\text { the noise coming from a generator must be inferior to } 45 \mathrm{~dB} \text { near houses } \\
\text { (value equivalent to a quietly conversation) }\end{array}$ \\
\hline
\end{tabular}


Table 4. Relationship between height of the wind turbine and visibility in the territory.

\begin{tabular}{ll}
\hline Height including the Wind Turbine Rotor $[\mathbf{m}]$ & ${\text { Sight Distance }[\mathbf{k m}]^{*}}^{*}$ \\
\hline Up to 50 & 15 \\
$51-70$ & 20 \\
$71-85$ & 25 \\
$86-100$ & 30 \\
$101-130$ & 35 \\
\hline
\end{tabular}

*The sight distance is the maximum distance in km from where you can see a wind turbine of given height (the height of the radius of the rotor together with those of the structure up to the hub).

the design and in the evaluation of projects, so that the landscape quality of sites constitutes an important reflection on the choice for territorial transformations.

This procedure will help:

- to propose rational development for the installation of windfarms in the region, through a computerized framework of knowledge, integrated to regional and local planning established by DRAG (Regional Document of General Layout) [16];

- to create an application protocol, as a system oriented both to the government control for the state of the works constantly in changing and updating, and to a framework for the development of the wind energy system, useful for private companies, to intervene according to the criteria established by regulation planning;

- to create a replicable, repeatable and adaptable model for different municipal needs with a degree of autonomy and above all a model accessible to any type of user, through computer channels (official website of the region), the same that will be constantly updated in a single database. This will help to ensure that data are accessible and that procedures on the information produced will be based on transparent criteria.

The instrument used to achieve the research objectives is the PUG (General Urban Plan) (Regional Law n. 20/2001) by including the requirements and guidelines for the proper and adequate planning of the municipality using the Cognitive Frameworks, i.e., Invariants Structural and Regional Contexts, such as those areas excluded from the construction of large and small size systems.

This research proposal uses the planning tool in a simple way together with the regional regulatory for a proper insertion of wind power plants in the area, and seems to be a good basis for building a tool for the identification of suitable areas, not suitable or partially suitable areas for the construction of windfarms, providing the results of the research.

The survey phase has started from the construction of the Regulatory Framework of reference, an international, national and local level, very useful to understand the management rules of the matter. Then it has been proposed an update of the cognitive frameworks of Puglia Landscape about environmental resources, landscapes, settlements and infrastructures (hydrography, morphology, vegetation, land use, urbanization, natural reserves, historic and scenic landscapes of international, national and local interest, scenic routes, areas of strong tranquillity or naturalness or full of symbolic meanings).

Finally, a census of the wind turbines already placed on the territory was created, their related features paying greater attention on any incompatibilities with landscape.

The final result is a database containing all the information relating to wind farms already present in the region above and below to $1 \mathrm{MW}$, including decommissioned plants too, as a result of a malfunction or a pure speculative action, specifying forms and procedures of their disposal.

\section{Suggested Model for the Environmental Integration of Wind Farms in the Countryside of Puglia}

The final aim of this research is the proposal of a model for the rational development of the installation of wind farms in the region, through a computerized framework of knowledge created after the survey phase, described in the previous paragraph, and integrated with the regional and local planning established by DRAG.

The model is developed on Arcgis, with the official map in Gauss-Boaga UTM 33, based on cadastral references 
Table 5. Areas suitable and unsuitable and their associated requirements for the integration of wind power plants $\left(^{*}\right)$.

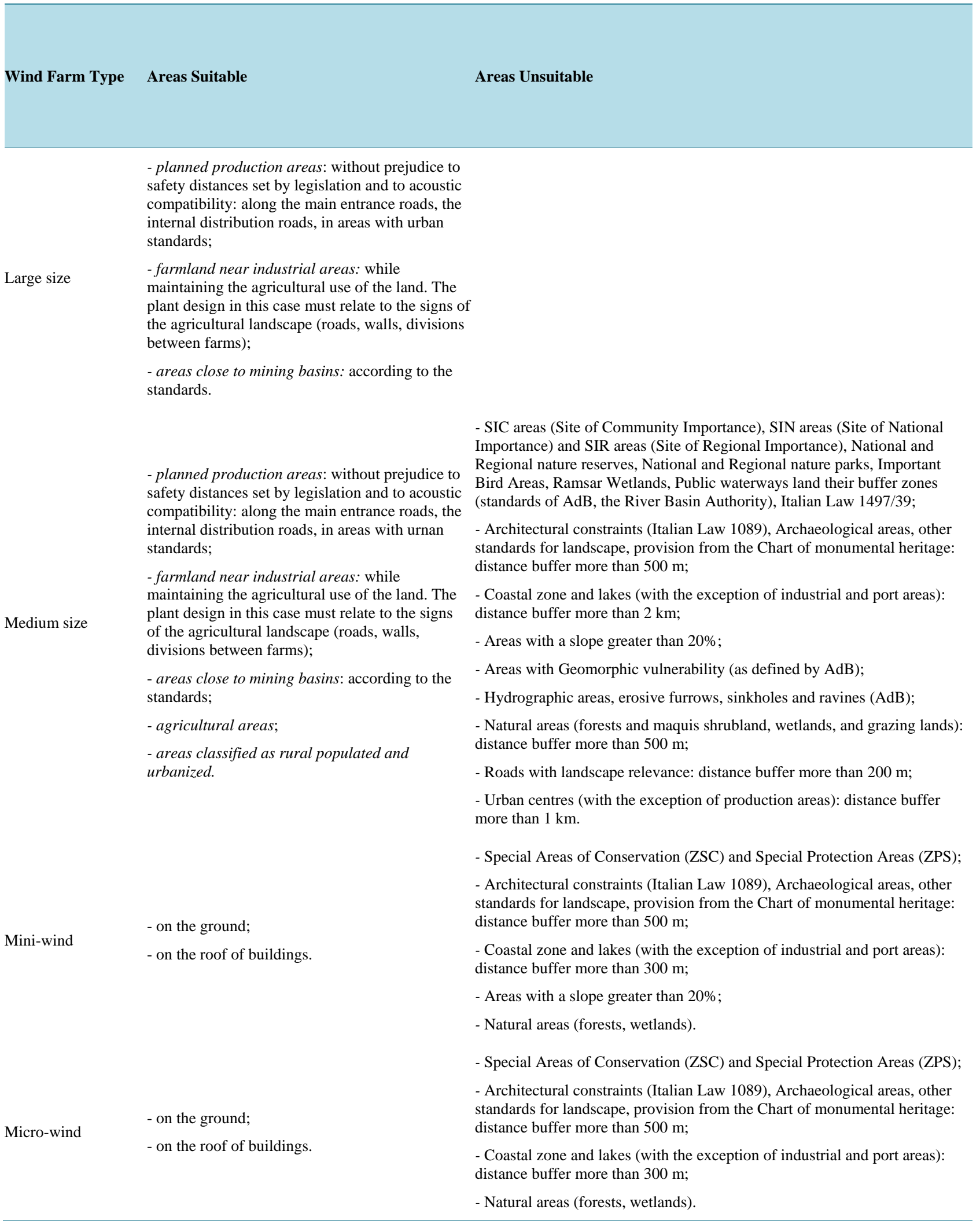

(“) Source: Linee guida sulla progettazione e localizzazione di impianti di energia rinnovabile-Regione Puglia. 


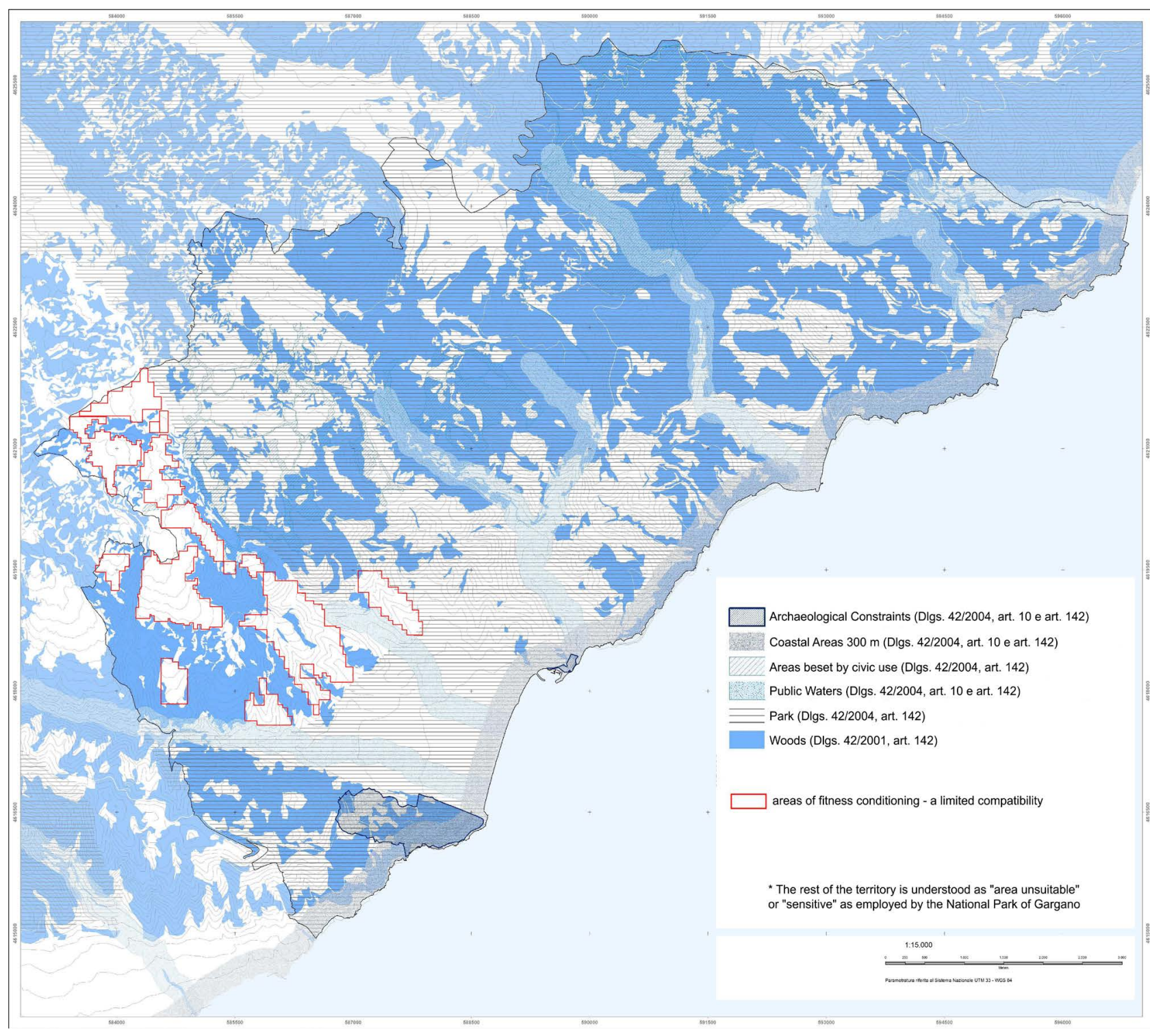

Figure 1. Structural Invariants represents the superordinate to PUG, according to National Law 42/2004.

updated to 2012 and the Regional Technical Map of 2008.

The goal of the system is to proceed overlaying invariant characteristics of a municipality reproduced in the cartography representative of the interested area (habitats and vegetation system, hydro-geomorphological system, historical-architectural system, settlement and infrastructure, topography, wind conditions, birds system, territorial and urban contexts defined by the PUG).

The result is summed in a series of inscribable maps gradually achieved, discarding areas in dangerous for the landscape and by the general characteristics, from which the result "in negative" allows the identification of areas:

a) not suitable-"sensitive": those areas characterized by elements of the natural system, settlement or town; in this case is prohibited to include any element to alter the status quo;

b) conditioned suitability-limited compatibility: for small size of wind turbines and directed to self-consumption, in those characterized areas that do not have ministerial and regional restrictions or safeguards. The new Regional Plan for Landscape (PPTR) addresses actions and projects towards self-consumption policies, addressed to municipalities and individual users;

c) appropriate-compatible: mainly those production areas and near the mining basins, where there are no ele- 


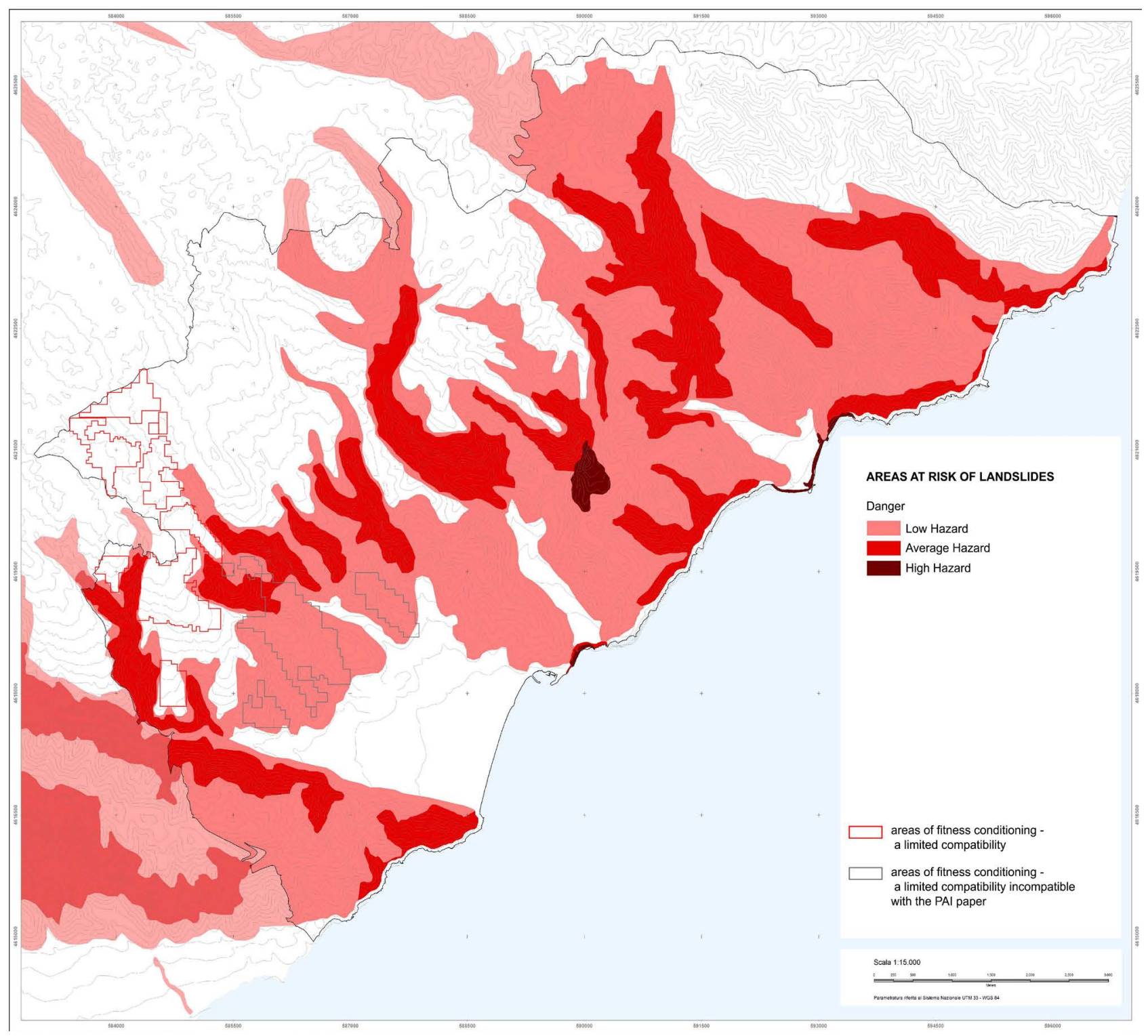

Figure 2. Structural Invariants represents the superordinate to PUG, according to the Hydrogeological Plan (PAI).

ments to protect. The PPTR aims to encourage the concentration of wind farms, photovoltaic and biomass plants in the industrial areas. In this direction it is important to reconsider the production areas as real power energy production areas where it is possible to design an integration of different technologies in symbiosis among them, for the benefit of the companies that use the electric and thermal energy produced. All this takes part of a wider scenario of design for Productive Areas for landscape and Ecologically Outfitted (APPEA).

To illustrate the application of the proposed model, it was applied to a case study, to the City of Mattinata, district of Foggia in the North of Puglia, characterized by good values of wind. The application of the protocol to install wind turbines in small and large sizes is divided into the following phases:

Phase 1-identification of structural invariants and spatial features (habitats and vegetation system, hydrogeomorphological system, historical-architectural system, settlement and infrastructure, topography, wind conditions, birds system, Italian Law n. 42/2004, Implementing Technical Standards of the Thematic Territorial Urban Plan (PUTT/P), Wind Atlas, regional laws and municipal ordinances);

Phase 2-identification of local urban and rural contexts areas (with the exception of the built-up area in rural zones and primarily to industrial and handcraft areas for large size plants); 


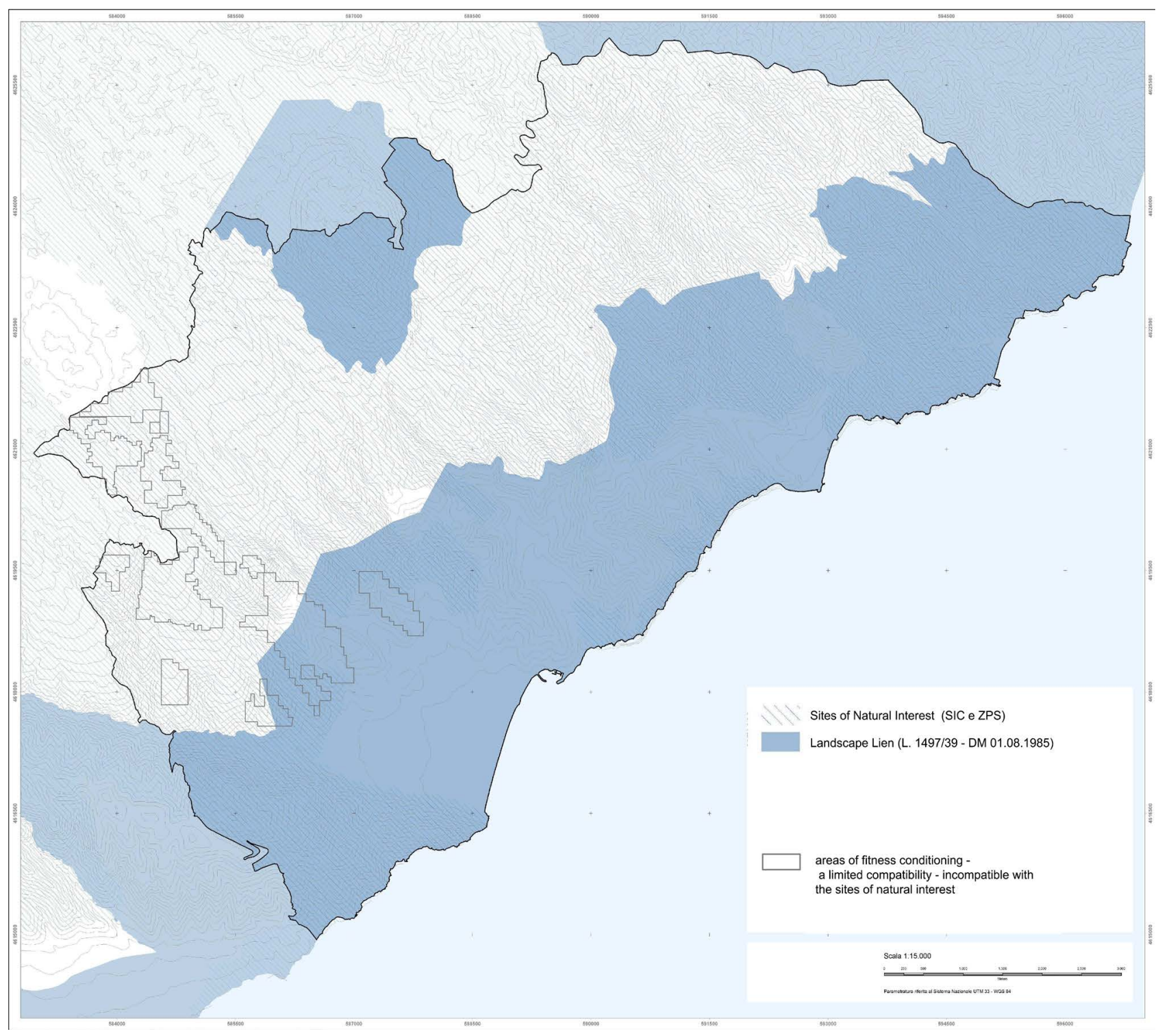

Figure 3. Sites of Nature represents a national scale (SIC and ZPS).

Phase 3-classification of macro-areas: not suitable-"sensitive"; conditioned suitability-limited compatibility and appropriate-compatible as described above. In such areas, it will be possible to predict or not the localization of the plants according to type and size permitted in the area and in the context;

Phase 4-in the previous phase we have identified macro-areas, that will be superimposed on the Cadastral Map, to point out in which particles it is possible to install a wind turbine and make the case clear and known to people involved.

The figures below indicate how the proposed model works.

Figure 1 shows the restrictions imposed by National Law 42/2004 [17] (archaeological restrictions, coastal areas with a buffer of $300 \mathrm{~m}$, public areas, public water, parks, woods) from which, in red, are indicated those areas in "conditioned suitability". The rest of the territory is "not suitable", a risk area, because it covers the 85\% of the Gargano National Park.

Figure 2, instead, shows the Hydrogeological Plan (PAI) constraints. In this overlap is clear that the areas of "conditioned suitability" (red) are reduced by eliminating those one drawn in grey because with a low and high hydro-geological risk.

Figure 3 shows that Natural Sites of national interest (SIC and ZPS) and the Landscape constraints 


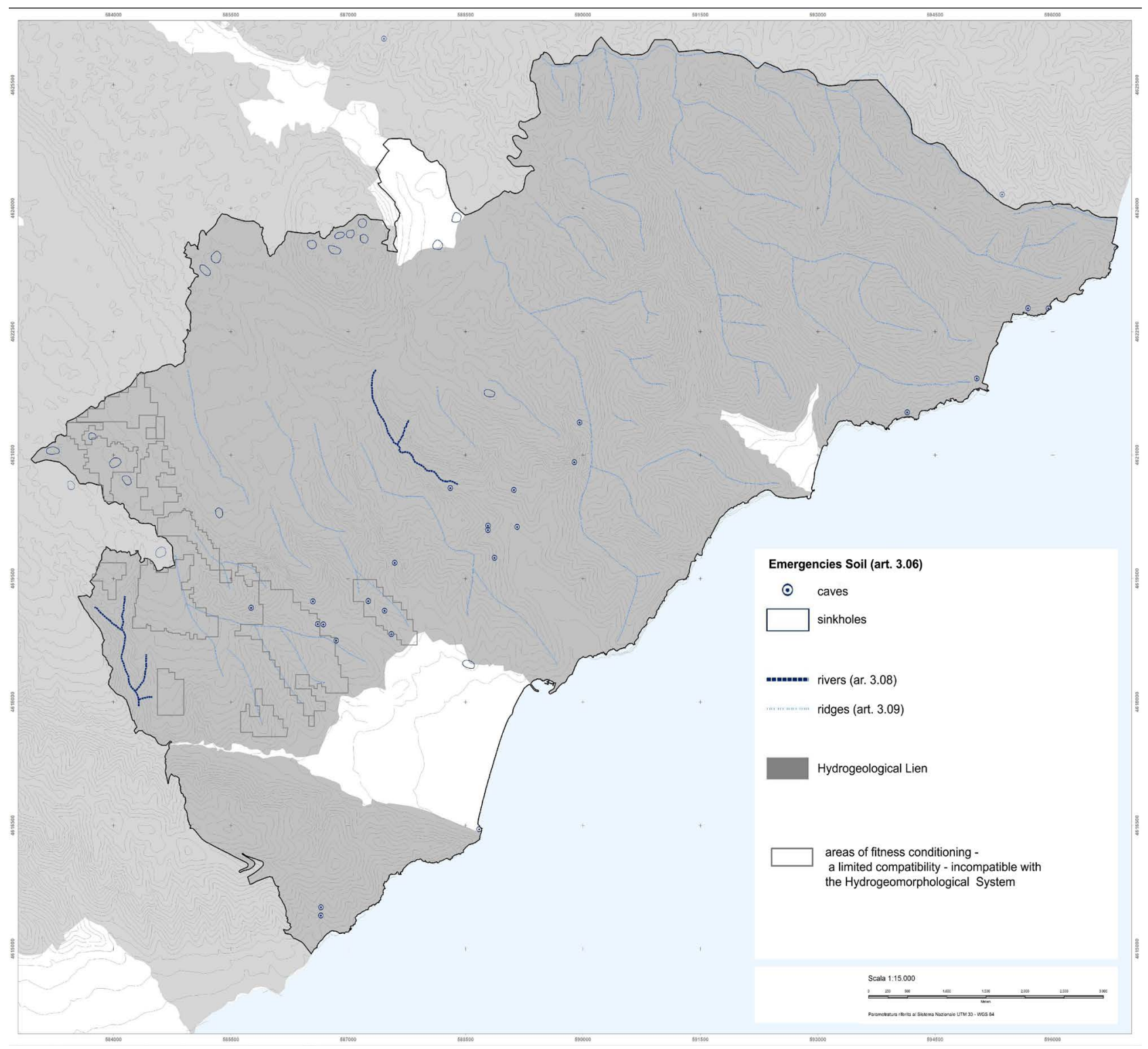

Figure 4. National constraints Invariants Structural System hydro-geomorphological (caves, sinkholes, rivers, ridges, hydrogeological restrictions) at the regional scale of the PUTT/P.

according to the Law 1497/1938. In this overlap all areas (gray) are "not suitable" for any insertion of plants.

Other overlap maps show on the Figure 4 an overwrite of hydro-geomorphological constraints (caves, sinkholes, rivers, ridges, hydrogeological restrictions) at the regional scale of the PUTT/P, according to the DGR 1748/2000, while the Figure 5 shows overlaying areas considered as "conditioned suitability" according to the constraints of national and regional habitats and vegetation system (woods, soil, natural assets and protected areas, sites of natural interest). Even in this case, the areas initially considered as "conditioned suitability" become "not suitable" areas (grey).

Figure 6 shows the additional overlaying areas considered as "conditioned suitability" according to the national and regional historic-cultural system (constraints, archaeological and architectural settlement, agricultural landscape-DGR 1748/2000).

Those areas initially considered as "conditioned suitability” become "not suitable” areas (grey).

Finally, Figure 7 shows an overlap of the areas considered as "conditioned suitability" according to national constraints listed in the draft of the PUG of Mattinata City (FG). According to this plan, all the areas should be 


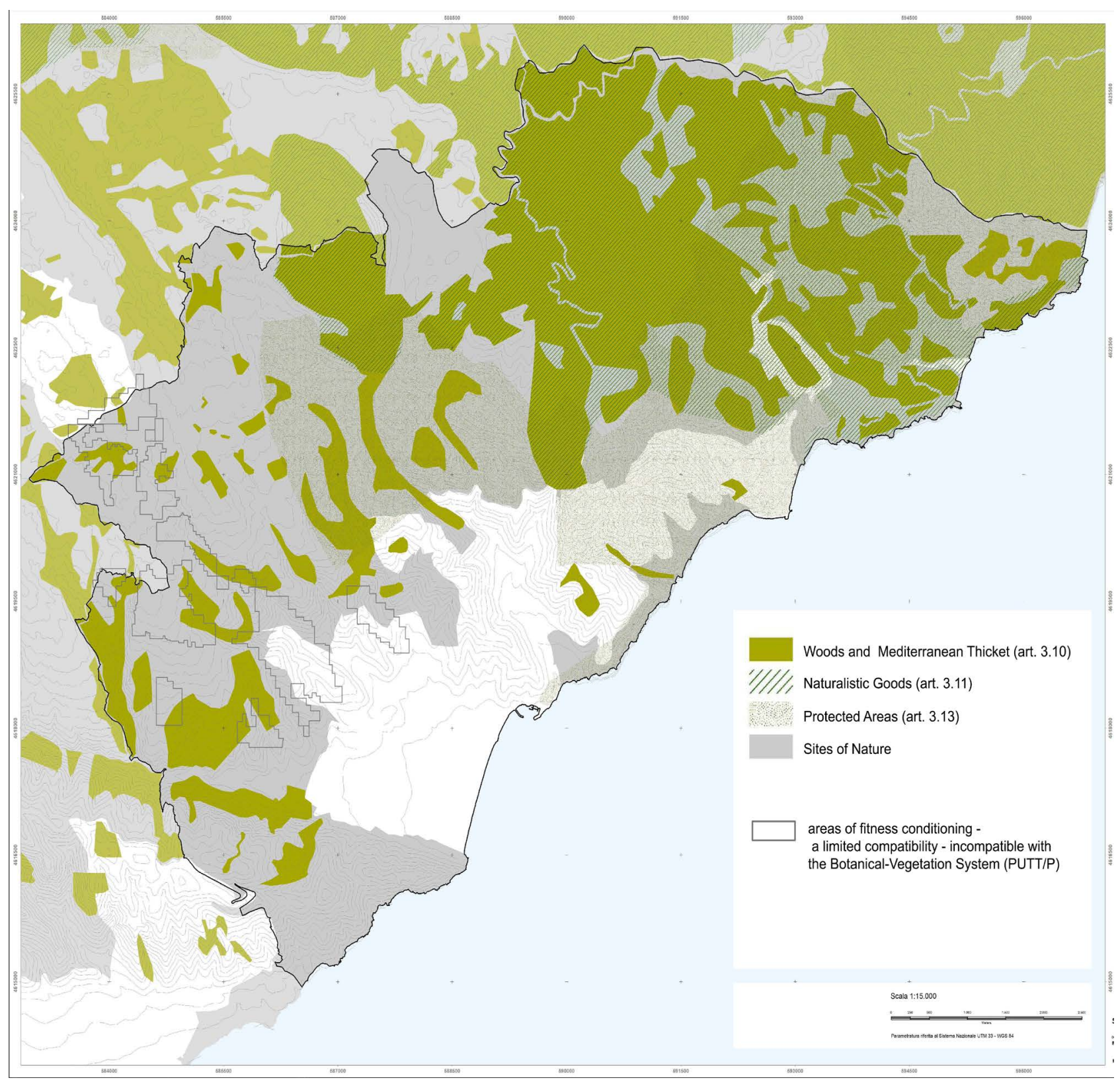

Figure 5. National constraints Invariants Structural System botanical-vegetation (woods, soil, natural assets and protected areas, sites of natural interest) at the regional scale of the PUTT/P.

part of agricultural contexts.

As additional information, Figure 8 shows the map of the wind according to the National Wind Atlas [18] with an indication of the wind speed in the examined areas.

The final results of the superposition of these maps shows that the application of the model did not produce any "suitable area" for the installation of wind farms; almost the entire territories is "not suitable" and under protection, since the territory include the $85 \%$ of the Gargano National Park.

In this borderline case, priority will be given to mini-wind finalized to self-consumption, applied to residential and industrial areas, which in this case are very reduced.

Therefore, even if the territory for geological and geographical location is "suitable" for the installation of the plants, the landscape value and the various constraints forbid their insertion.

The thesis supported by this research aimed to create a tool for the identification and location of those areas 


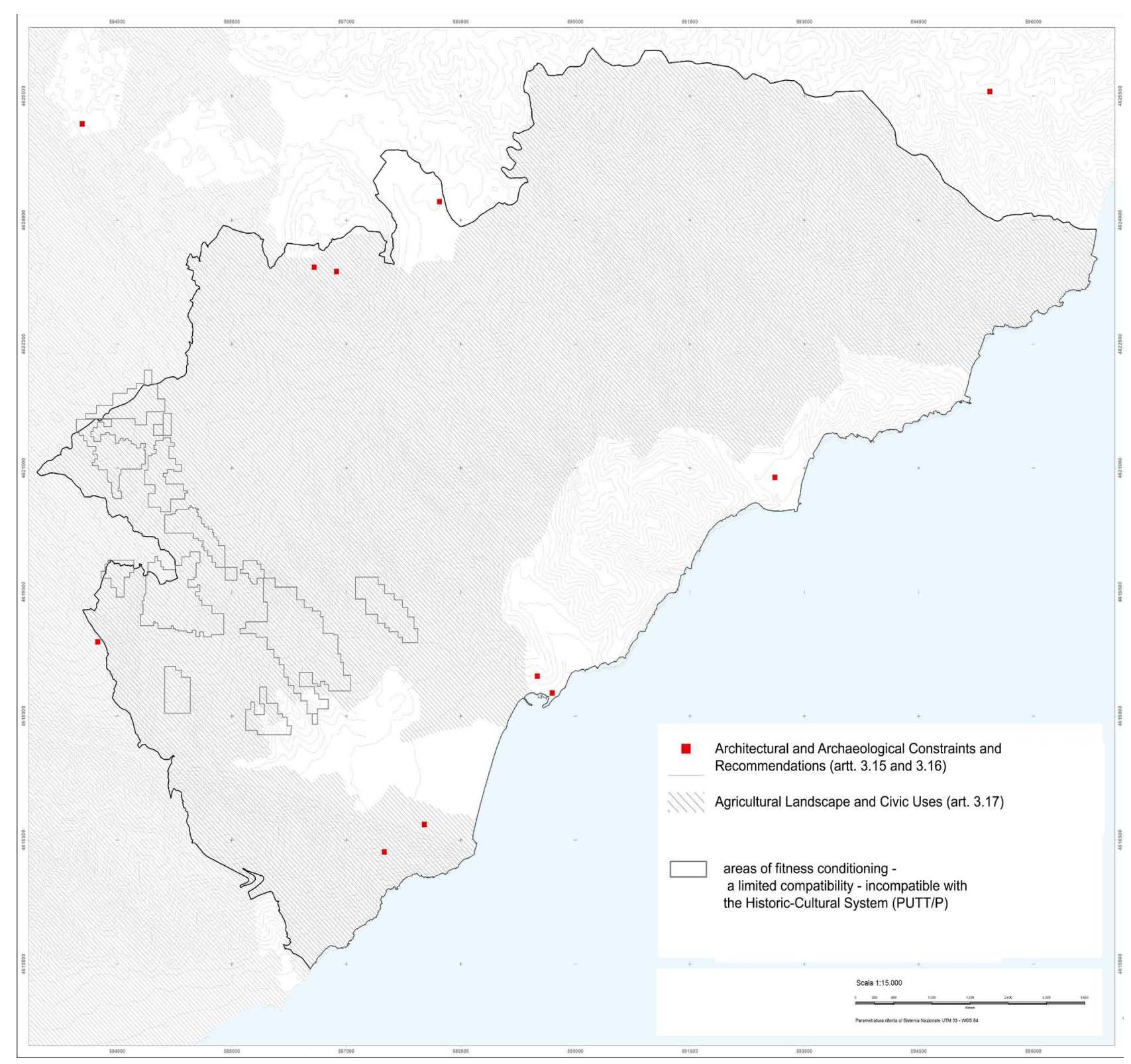

Figure 6. National constraints Invariants Structural System historic-cultural (constraints, archaeological and architectural settlement, agricultural landscape. DGR 1748/2000) at the regional scale of the PUTT/P.

with suitable or partially suitable characteristics for the insertion of a wind farm, thanks to this method and tools, it is considered useful and applicable to other cases to plan a PUG.

In this way it is possible to create an interactive and available method for companies and individuals interested in the installation of wind turbines, available on the municipal authorities' official websites to check the suitability of areas instead of a failed authoritative process by local government.

This would also facilitate the drafting of a Landscape Report which is attached to the authorizations and to the Environmental Impact Assessment; it could be simpler to have for all different cases the data available for a proper construction and permit's procedures.

Anyway, it is possible to check all the cases because the identification of the suitable areas does not deplete all areas right for wind plants, rather it suggests potential areas that can be examined in depth in local planning.

Other areas may be identified also in regional planning processes after the check of the energy producibility based on data collected by more accurate anemometers and of the environmental compatibility of selected areas. 


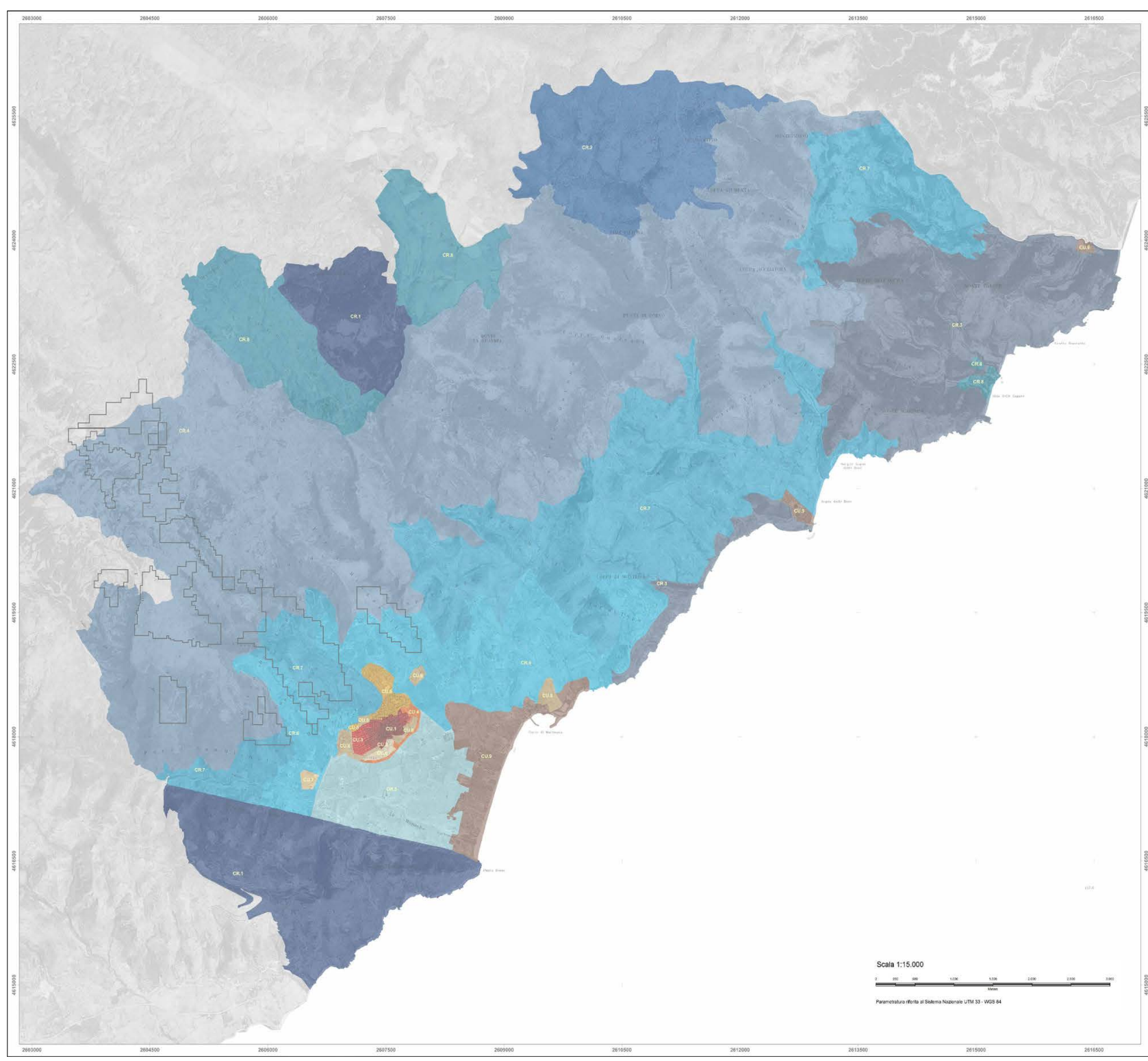

Figure 7. Overlap of conditioned areas PUG of Mattinata City (FG).

\section{Conclusions}

In this paper, it has been tested an application protocol to find the suitable area for the installation of wind farms, according to criteria defined in areas established by planning and standards. This procedural model is directed both to a government to control the state of the constantly changing and updating works, and to private companies as a framework for the check of the feasibility of the project to avoid the additional costs of design.

The model is replicable, repeatable and adaptable to different municipal needs with a degree of autonomy and, above all, is a model accessible to any type of user, through the official website of the Region continuously updated in a single database.

This ensures the accessibility of the data with a transparency on the procedural criteria and on the accuracy of the information.

This procedural model facilitates the understanding of the procedures for the evaluation of a wind farm project and those relating to the landscape authorizations necessary to overcome some delays and bureaucratic- 


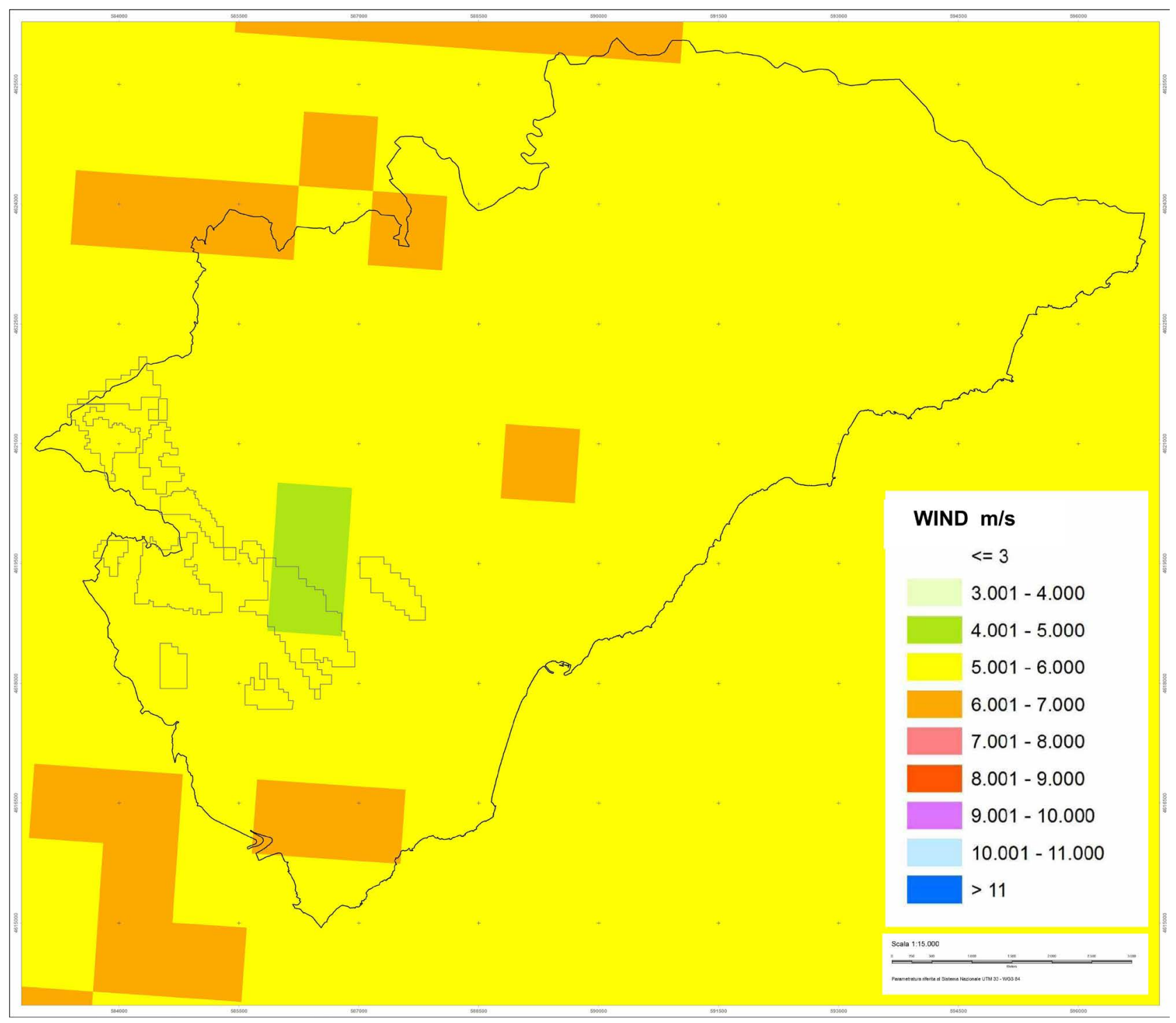

Figure 8. National wind atlas CESI.

complexities that often degrade the quality of the project.

\section{References}

[1] Pantaleo, A., Pellerano, A., Ruggiero, F. and Trovato, M. (2005) Technical and Economical Feasibility of Off-Shore Wind Farms. Solar Energy, 79, 321-331. http://dx.doi.org/10.1016/j.solener.2004.08.030

[2] Ruggiero, F., Forte, G., Dicorato, M. and Trovato, M. (2009) Energy Potential from Off-Shore Wind Farms in the Mediterranean Sea. Proceedings of SEEP 2009 Dublino (Irlanda), August 2009.

[3] Kondili, E., Kaldellis, J.K. (2012) 2.16-Environmental-Social Benefits/Impacts of Wind Power. Comprehensive Renewable Energy, Volume 2: Wind Energy, 503-539

[4] Mays, I.D. (1994) The Environmental Benefits and Implications of Wind Energy. Renewable Energy, 5, 537-541.

[5] Evans, A., Strezov, V. and Evans, T.J. (2009) Assessment of Sustainability Indicators for Renewable Energy Technologies. Renewable and Sustainable Energy Reviews, 13, 1082-1088. http://dx.doi.org/10.1016/j.rser.2008.03.008

[6] Saidur, R., Rahim, N.A., Islam, M.R. and Solangi, K.H. (2011) Environmental Impact of Wind Energy. Renewable and Sustainable Energy Reviews, 15, 2423-2430. http://dx.doi.org/10.1016/j.rser.2011.02.024

[7] Gross, C. (2007) Community Perspectives of Wind Energy in Australia: The Application of a Justice and Community 
Fairness Framework to Increase Social Acceptance. Energy Policy, 35, 2727-2736. http://dx.doi.org/10.1016/j.enpol.2006.12.013

[8] Clarkea, A. (1989) Wind Farm Location and Environmental Impact. International Journal of Ambient Energy, 10, 129-144. http://dx.doi.org/10.1080/01430750.1989.9675132

[9] Bell, D., Gray, T., Haggett, C. (2005) The “Social Gap” in Wind Farm Siting Decisions: Explanations and Policy Responses. Environmental Politics, 14, 460-477. http://dx.doi.org/10.1080/09644010500175833

[10] Szarka, J., Cowell, R., Ellis, G., Strachan, P.A. and Warren, C. (2012) Learning from Wind Power Governance, Societal and Policy Perspectives on Sustainable Energy. Series: Energy, Climate and the Environment, Palgrave Macmillan Editor.

[11] GSE (Gestore Servizi Energetici) (2011) Statistical Report 2011 Plants to Renewable Energy Sources. GSE, Italy.

[12] Directive 2009/28/EC of the European Parliament on the Promotion of the Use of Energy from Renewable Sources and Amending and Subsequently Repealing Directives 2001/77/EC and 2003/30/EC.

[13] Scottish Guidelines (2006) Visual Analysis of Windfarms. Good Practice Guidance. Scottish Natural Heritage.

[14] Italian Law n. 387/2003 (2003) Implementation of the Directive 2001/77/EC on the Promotion of Electricity Produced from Renewable Energy Sources in the Internal Electricity Mark.

[15] Regional Law n. 25/2012 (2012) Regulation of the Renewable Energy Sources.

[16] Regional Law n. 20/2001 (2001) General Rules of Governance and Land Use.

[17] Italian Law n. 42/2004 (2004) Code of Cultural Heritage and Landscape, in Accordance with Article 10 of the Law No. 137 July 6, 2002.

[18] CESI (2009) Wind Atlas of Italy. 
Scientific Research Publishing (SCIRP) is one of the largest Open Access journal publishers. It is currently publishing more than 200 open access, online, peer-reviewed journals covering a wide range of academic disciplines. SCIRP serves the worldwide academic communities and contributes to the progress and application of science with its publication.

Other selected journals from SCIRP are listed as below. Submit your manuscript to us via either submit@scirp.org or Online Submission Portal.
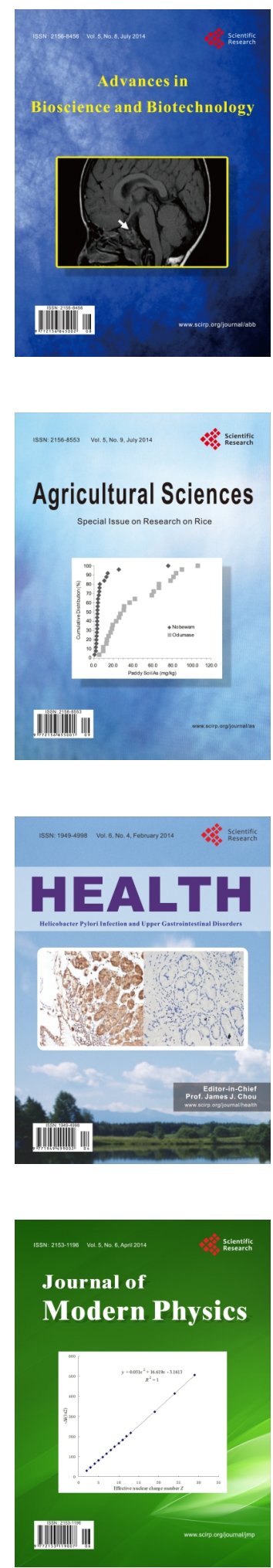
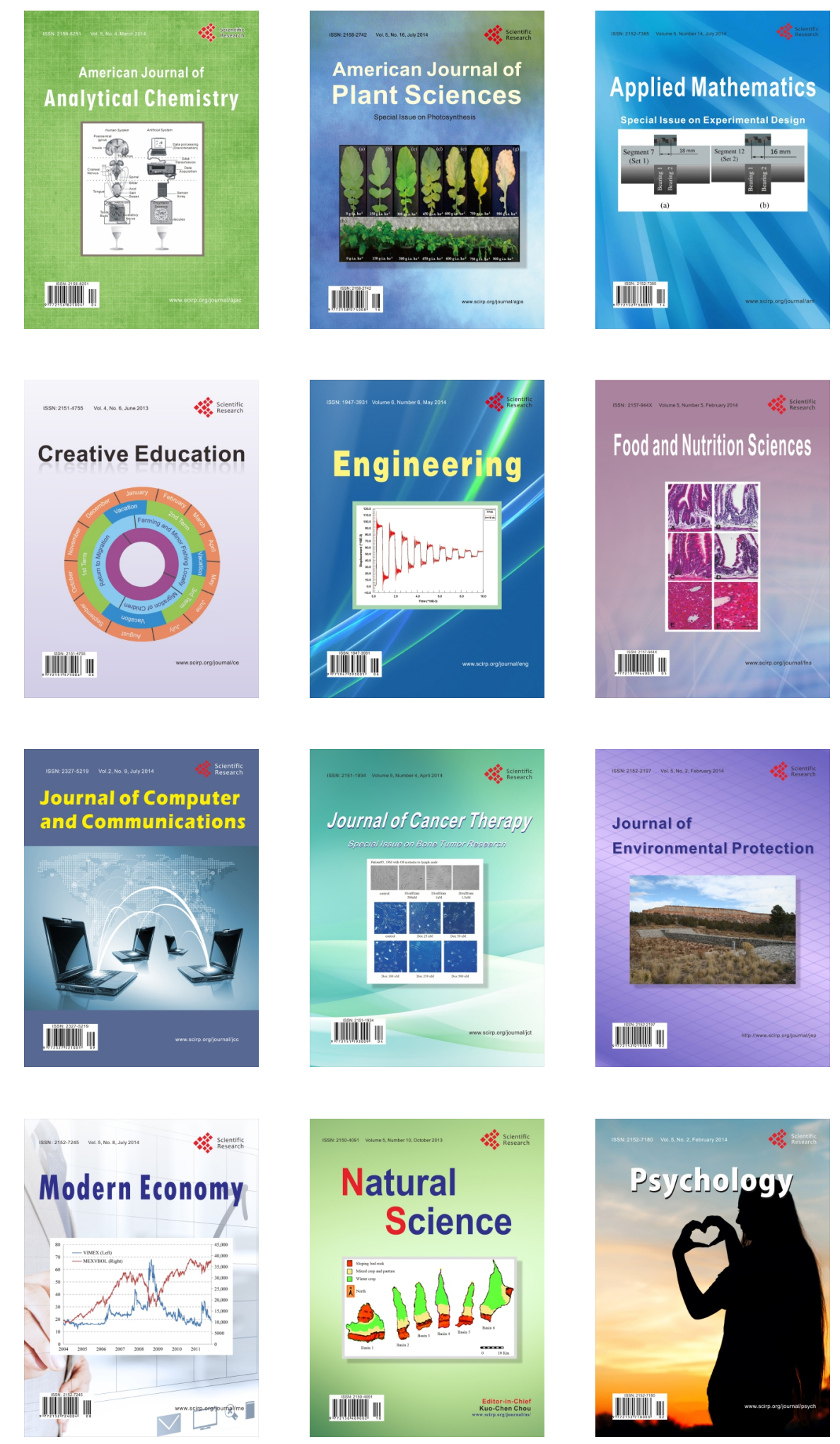